\title{
Statistical analysis correlating changing agronomic practices with nitrate concentrations in a karst aquifer in Ireland
}

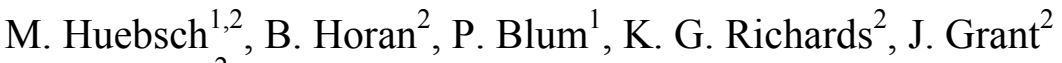 \\ \& O. Fenton ${ }^{2}$ \\ ${ }^{1}$ Karlsruhe Institute of Technology, Germany \\ ${ }^{2}$ Teagasc, Ireland
}

\begin{abstract}
The correlation of nitrate $\left(\mathrm{NO}_{3}^{-}\right)$occurrence in groundwater with nitrogen $(\mathrm{N})$ applications resulting from intensive agriculture sited on thin free draining soils and karstified limestone is often difficult and therefore avoided. This is unfortunate as groundwater $\mathrm{NO}_{3}{ }^{-}$concentrations in these environments react the quickest to farm management changes. The objective of the current study was to evaluate local weather conditions, (hydro-) geological site characteristics and detailed agronomic N-loadings with groundwater $\mathrm{NO}_{3}{ }^{-}$occurrence by using a statistical tool during a study period from 2002 to 2011 . The statistical analysis involved a multiple linear regression with automatic variable selection. Four scenarios were created to compare paddock specific changes to groundwater wells. In addition, a time lag from source to groundwater of up to 3 years was considered. In particular, the results suggested that agronomic practices became more important after a time lag of 1 to 2 years and agronomic practices such as: reductions in inorganic fertilizer application, changes of timing of slurry application, the relocation of a dairy soiled water irrigator to a less karstified area and the implementation of minimum cultivation reseeding instead of ploughing, led to reduced $\mathrm{NO}_{3}{ }^{-}$occurrence in the aquifer. The present approach is a suitable tool to elucidate the consequences of agronomic practices on groundwater quality and can be used in vulnerable areas for the assessment of present and future legislation implementation.
\end{abstract}

Keywords: karst, groundwater, nitrate, agriculture, farm management. 


\section{Introduction}

Environmentally sustainable, economically viable and productive farming systems are required to meet the growing worldwide need for agriculture produce [1]. In Ireland, agriculture is dominated by dairy and beef cattle production from managed grassland [2]. Global population growth is predicted to increase the demand for food by up to $100 \%$ by 2050 [3]. The European Union (EU) milk policy is due to change radically in 2015 with the abolition of farm level milk quotas and a target of a $50 \%$ increase in milk production in Ireland has been proposed by the Food Harvest report by 2020 [4]. Such highly ambitious growth targets for the agri-food sector must be achieved within current EU environmental legislation and will be further exacerbated by climate change. The EU Water Framework Directive (WFD) [5] is a multi-part and multi-stage piece of legislation that aims, inter alia, to achieve at least "good" water quality status in all water bodies by 2015 with programmes of measures (POM) to achieve such a status implemented by 2012. In Ireland, the Nitrates Directive [6] implemented since 2007 is Ireland's agricultural POM. This Directive places restrictions on all potential nitrogen $(\mathrm{N})$ inputs into a farming system including: cattle stocking rates with a default of $170 \mathrm{~kg} \mathrm{~N}$ per ha-1 or $250 \mathrm{~kg} \mathrm{~N}$ per ha-1 on derogation farms (present study site), organic and inorganic fertilizer rates of use, the time of spreading and their storage. In general 59\% of Ireland's river, over $47 \%$ of the lakes, $64 \%$ of the estuaries and $85 \%$ of the groundwater are already at "good" to "high" ecological status [7]. For areas where the targets of the WFD are not achieved by 2015 further legislative steps may be taken in areas of non-compliance and this could reduce farm productivity or at least add to production costs in some circumstances [8]. Exploring relationships between farm management practices and groundwater water quality is further complicated due to nutrient time lags from source to receptor via hydrological and hydrogeological pathways and it is now clear that the achievement of WFD targets by 2015 may not be possible in some cases [9]. Areas with thin overburden and heterogeneous underground such as karstified limestones are most vulnerable and react quickest to farm management changes.

The objective of this study was to relate changes in farm management with groundwater quality over a 10 year period on an intensive dairy farm with free draining soils and a vulnerable limestone aquifer, whilst also considering time lag.

\section{Methods}

\subsection{Site description}

A total of 48.1 ha of permanent grassland containing greater than $80 \%$ of perennial ryegrass (Lolium perenne) and grazed exclusively by dairy cattle was used for the duration of the study. The study site is located in a carboniferous limestone area in southern Ireland up-gradient of the River Funshion and a public water supply well (Figure 1). The perennial grassland farm is located on a 
limestone plateau with flat topography and negligible runoff. The soil on site (to a depth of $4.5 \mathrm{~m}$ ) is freely drained acid brown earth, derived from mixed sandstone-limestone glacial till overlying a karstified limestone bedrock aquifer and reflects $1.69 \%$ of the land area of Ireland [10]. The study site consists of 11 boreholes (BH 1-12) drilled at different stages since 2001 and are distributed across the entire farm (Fig. 1). Three wells $(\mathrm{BH} \mathrm{4,11,12)}$ are $150 \mathrm{~mm}$ diameter open boreholes and the remainder consist of a $50 \mathrm{~mm}$ diameter piezometer casing. Mean drilling depth on site is $40.8 \mathrm{~m}$ (min depth of $22 \mathrm{~m}(\mathrm{BH} 5)$ and max depth of $59.5 \mathrm{~m}(\mathrm{BH} 3)$.

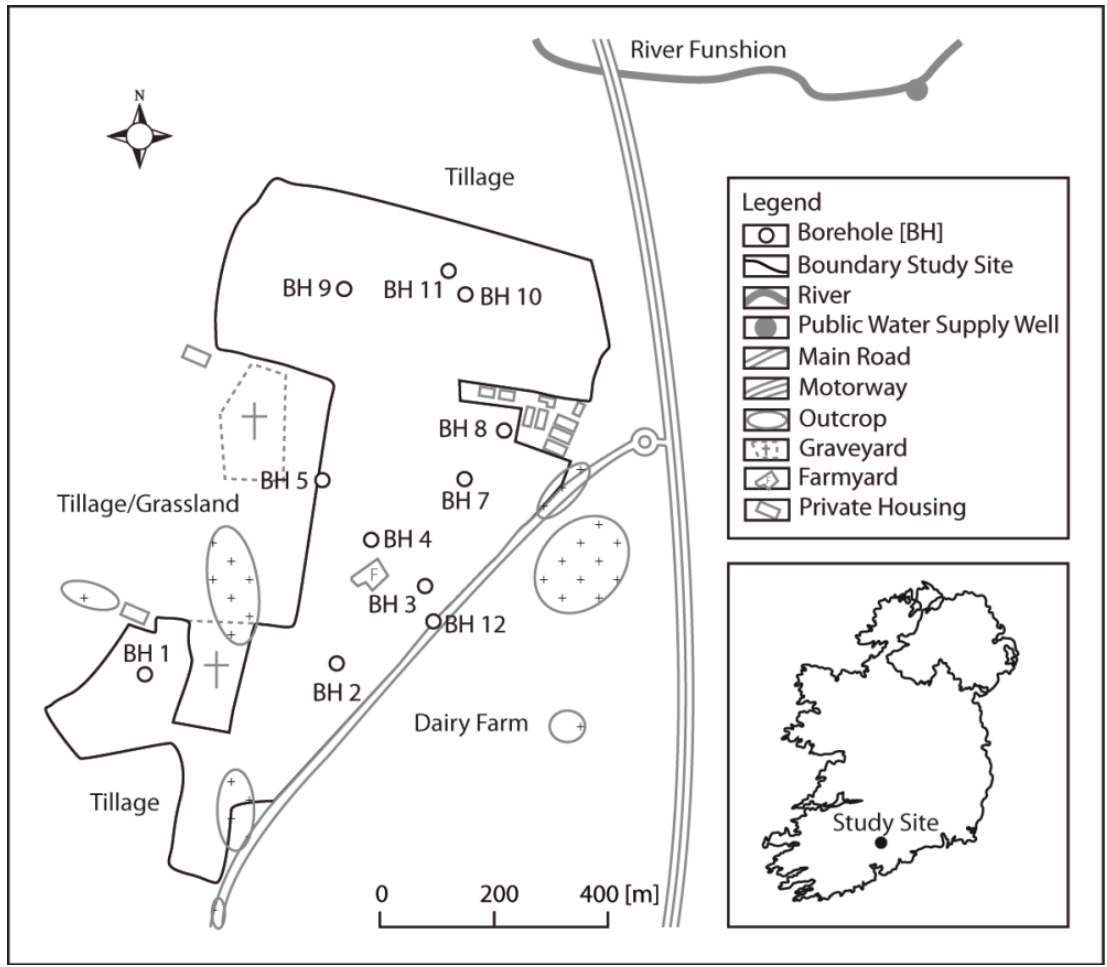

Figure 1: Site map of the study area.

\section{2 (Hydro-) geologic, local weather and agronomic monitoring}

A farm-scale hydrogeological investigation was established in 2001 to measure nitrate-N losses to groundwater monthly from 2002. Groundwater sampling, transport to the laboratory and analysis followed the procedures of [11] for nitrate $\left(\mathrm{NO}_{3}-\mathrm{N}\right)$, nitrite $\left(\mathrm{NO}_{2}-\mathrm{N}\right)$ and ammonium $\left(\mathrm{NH}_{4}-\mathrm{N}\right)$. Briefly, after purging the previous day, a Waterra hand-held pump (Van Walt Ltd., Surrey, UK) was used to collect $100 \mathrm{ml}$ of groundwater. The samples were filtered immediately, using a $0.45 \mu \mathrm{m}$ micropore membrane filter, transferred to polyethylene screw top bottles, and frozen prior to chemical analysis. Water table depths were 
measured regularly (72 times) between July 2001 and September 2003, sporadically between 2004 and 2011 and more intensively for a few weeks in May 2011 for a shorter period. A land survey was performed for achieving values in meter AOD (above ordinance datum). The measurements were taken at least at one point within each paddock of the farm and at the wells. All well elevations were surveyed and water table depths converted to hydraulic heads in m AOD (above ordinance datum). Such data allowed water table fluctuations and groundwater flow directions to be ascertained (Figure 2). A bromide tracer test was performed around $\mathrm{BH} 7$ by [12], that indicated a hydrogeological pathway from $\mathrm{BH} 7$ to $\mathrm{BH}$ 6, BH 9 and $\mathrm{BH}$ 10. In addition, a geophysical survey was carried out to determine surface conductivity (to $6 \mathrm{~m}$ depth) and resistivity (to $50 \mathrm{~m}$ depth) and therefore, to ascertain lateral and vertical variations in overburden material, depth to bedrock and bedrock lithology. An elongated conduit system was observed trending from north-west to south-east in the middle of the farm. Data from [10] was also used in the present study. Soil samples were taken from 96 ceramic cups (depths) on 4 different treatments on the farm on a weekly basis during the autumn spring drainage period from October 2001 to April 2005. This practice involved 33, 37, 26 and 24 sampling

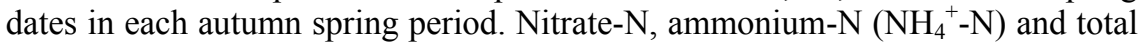
nitrogen (TN) were analysed.

Daily measurements of average, minimum and maximum air temperature, total solar radiation and daily rainfall were recorded at the experimental site during the study period. Daily meteorological input parameters (rainfall, temperature and sunshine hours) were inputted into the hybrid model for Irish grasslands of [13] to elucidate daily soil moisture deficit, actual evapotranspiration and effective drainage.

The total $\mathrm{N}$ inputs at the paddock level (weighted on the basis of paddock size) in the form of both chemical fertilizer, slurry and dirty water (DW) were recorded monthly during the study while off-takes of harvested grass for silage conservation were deducted. The frequency and intensity of grazing was recorded as the number of grazing days per hectare per month for each paddock. Approximately, $15 \%$ of the total farm area was reseeded annually from 2006 to 2011. In 2006 and 2007, seedbed preparation for reseeding was achieved by ploughing however this practice was discontinued and replaced by minimum tilling cultivation techniques from 2008 onwards.

\subsection{GIS applications}

A spatial analysis of the farm was carried out by using GIS applications. Total agronomic $\mathrm{N}$ inputs on the surface were compared on paddock level with $\mathrm{NO}_{3}{ }^{-}$ occurrences in all wells on a yearly basis as well as for the whole period.

\subsection{Statistical analysis}

To evaluate the relationship between local weather conditions, (hydro-) geologic and agronomic factors and changes in farm management practice multiple linear regression was chosen as statistical tool by using the aforementioned collected 
data. As explanatory variables were chosen: (1) local weather conditions: Rainfall, effective drainage, temperature, sunshine, soil moisture deficit, (2) (Hydro-)geologic factors: Thickness of soil and epikarst, open well or well with piezometer casing, maximum and minimum water table above ordinance datum taken from 72 measurements between 2001 and 2003 after [12], range of water table deviation, hydraulic conductivity, surface conductivity (3) agronomic factors: fertiliser, slurry and dirty water application, reseeding, silage and grazing. The response variables for the regression analysis were all related to groundwater quality and included $\mathrm{NO}_{3}^{-}, \mathrm{TON}, \mathrm{NO}_{2}^{-}$and $\mathrm{NH}_{4}^{+}$. Four cases were created to incorporate possible relations from $\mathrm{N}$ loading on the surface and $\mathrm{NO}_{3}{ }^{-}$ detection in groundwater. As the agronomic inputs and outputs for the paddocks were available on an annual basis, the monthly measurements and records were summarised for the analysis. The variables were modelled using Normal distribution based regression except for $\mathrm{NO}_{2}^{-}$and $\mathrm{NH}_{4}{ }^{+}$observations as these were heavily censored below the limit of detection. Therefore a count of detections was used in a logistic regression based on the proportion of detections observed. To assess evidence of time lag in the observed processes, farming variables were lagged from zero to 3 years (based on [14]) and the effect on variable selection was explored. The size of $\mathrm{F}$ and Wald statistics was used for the interpretation of relative importance in the factors influencing $\mathrm{NO}_{3}^{-}$ concentrations in groundwater.

For $\mathrm{NO}_{3}^{-}$, TON, $\mathrm{NO}_{2}^{-}$and $\mathrm{NH}_{4}^{+}$two approaches were taken. The first approach included fitting year as a factor in the models, effectively examining processes within year and allowing a broad assessment of the extent to which the measured variables in the data set were sufficient to describe the overall processes. The second approach used only the measured variables and provided an approximation to the best description of the physical process that was possible with the information available. Without year as a factor all changes over the period of investigation have to be 'explained' explicitly by the fitted model. As a consequence of numerical difficulties with the data for TN and DON only cases without year as a factor were reliable and therefore used for evaluation.

Four cases were proposed for this exploratory modelling (Figure 2). Each Case defined sets of paddocks for each borehole that were likely to contribute to the observed responses. The different Cases were based on topographic assumptions (e.g. concentric distribution of paddocks around the borehole) and the hydrological assumptions on groundwater pathways from an on-site tracer experiment [12]. The Cases were as follows: 1) One paddock was associated with a borehole within this paddock. 2) An assumption of relationships was made between paddocks and boreholes using a small catchment area with 25 paddocks by reverting to the known hydrological pathways from tracer experimental data and the general groundwater flow direction trending from southwest to northeast. 3) Focusing on topographic assumptions hypothesised a concentric relationship between boreholes and paddocks. 4) Same assumptions were taken as stated in 2) but with a greater catchment area with 34 paddocks involved. In total 96 runs were evaluated for all scenarios. 

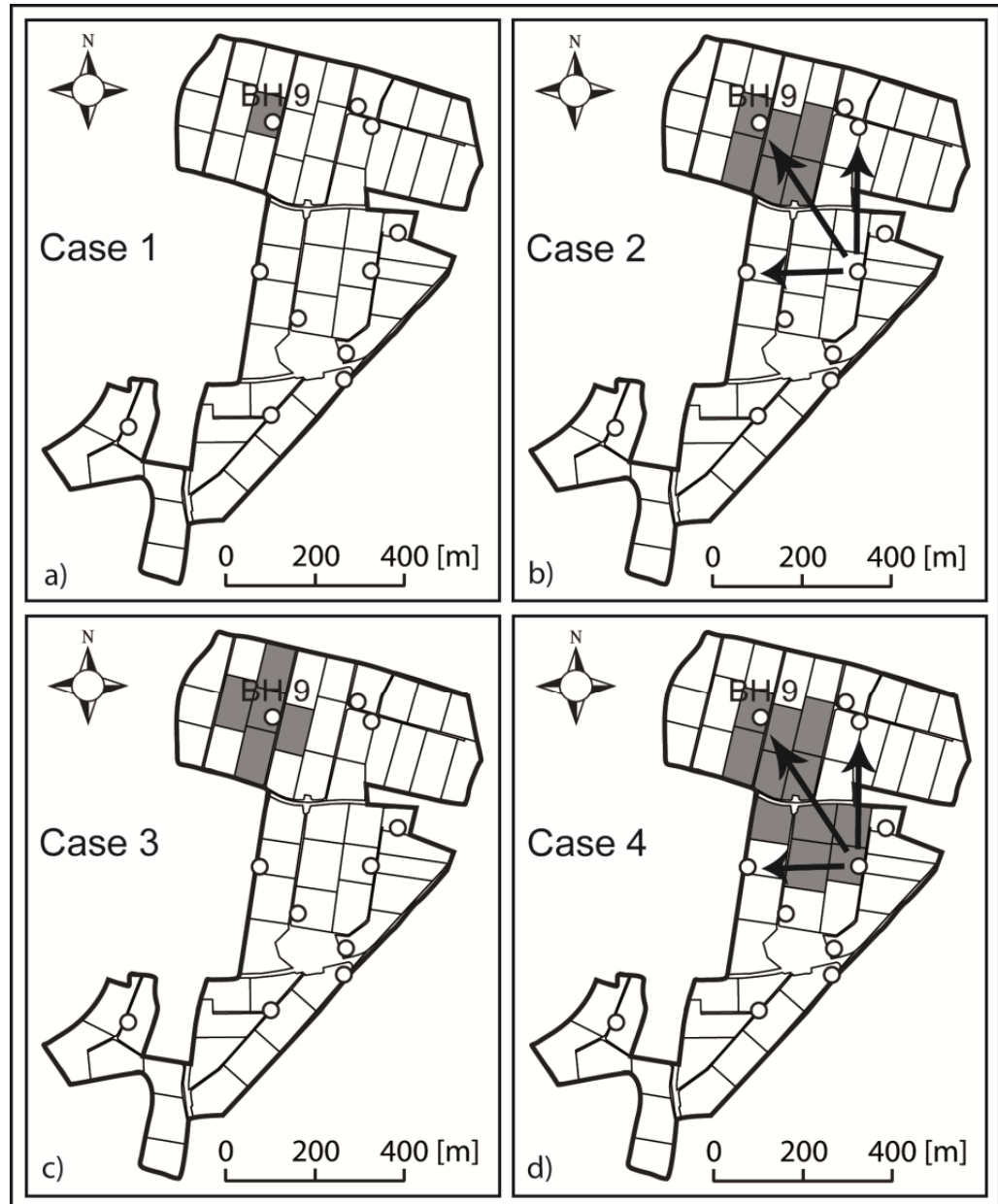

\begin{tabular}{|l|}
\hline Legend \\
$\square$ Borehole [BH] \\
$\square$ Boundary Study Site $\square$ Paddock Contour \\
$\square$ Hydrogeological Pathways after Bartley (2003)
\end{tabular}

Figure 2: Paddock to borehole relationship of Cases 1-4 as used in the regression analysis taking $\mathrm{BH} 9$ as an example. a) One paddock associated with a borehole within this paddock. b) The assumption of paddock to borehole relationship was made using a small catchment area (25 paddocks for all boreholes) by reverting to the known hydrogeological pathways from a tracer experiment [12] and the general groundwater flow direction towards northeast. c) Topographic assumption using concentric relationship. d) Same assumptions were taken as in [b] but with a greater catchment area (34 paddocks for all boreholes). After [15]. 


\section{Results}

\subsection{Groundwater quality trends}

$\mathrm{NO}_{3}{ }^{-}$concentrations were highly variable throughout the study. Between autumn and early winter greatest concentrations were monitored. In addition, at the beginning of the monitoring period in 2002 some very high $\mathrm{NO}_{3}{ }^{-}$concentrations were observed (up to $59 \mathrm{mg} / 1 \mathrm{NO}_{3}-\mathrm{N}$ ) close to two boreholes $(\mathrm{BH} 7$ and $\mathrm{BH}$ 8) in the middle of the farm when the DW irrigator was active in this highly vulnerable area. On average, groundwater $\mathrm{NO}_{3}{ }^{-}$concentrations decreased over the study period from $16 \mathrm{mg} / \mathrm{l}$ in 2002 to $7.3 \mathrm{mg} / 1$ during 2010 with a low of $6.6 \mathrm{mg} / \mathrm{l}$ in 2011. During the first 7 years of the study, overall mean concentrations were similar or exceeded the maximum allowable concentration (MAC) in groundwater stipulated by the WFD in Ireland $\left(11.3 \mathrm{mg} / \mathrm{l} \mathrm{NO}_{3}-\mathrm{N}\right)$. For the last 3 years of the study period (2009 to 2011) $\mathrm{NO}_{3}{ }^{-}$concentrations declined below the MAC.

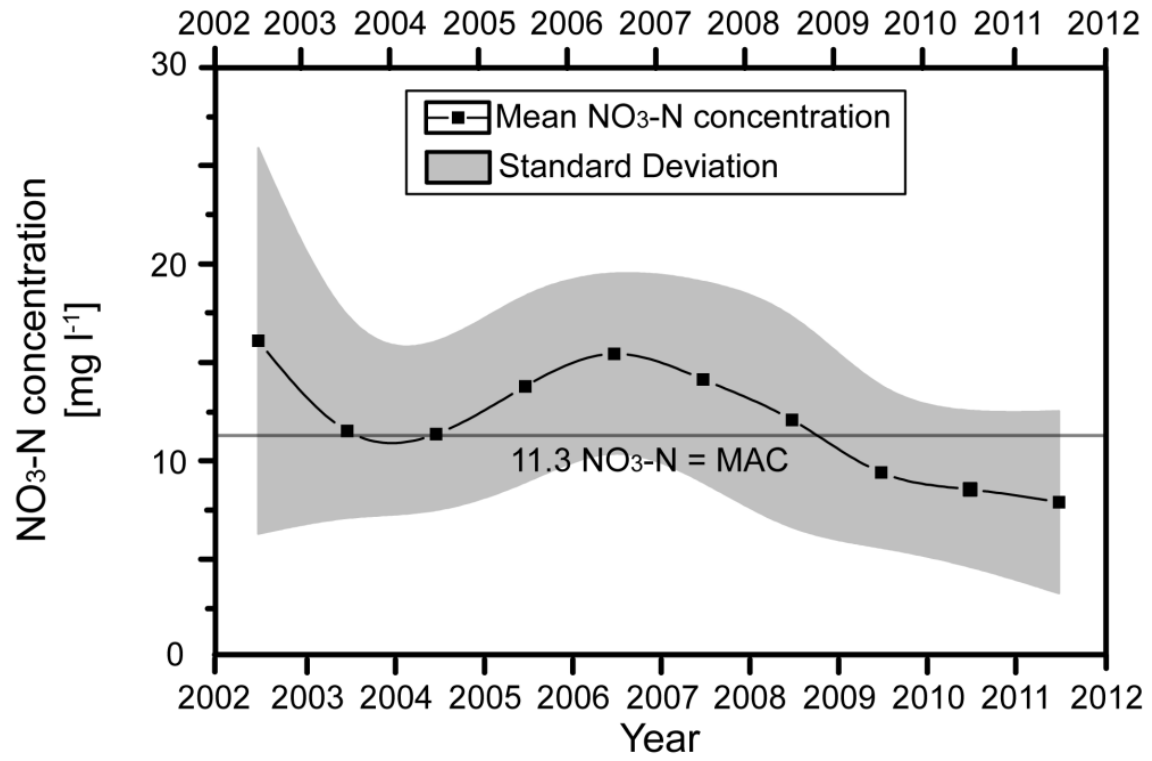

Figure 3: Mean $\mathrm{NO}_{3}-\mathrm{N}$ concentrations between 2002 and 2011.

\subsection{Spatial analysis}

The spatial analysis of the farm by using GIS applications brought no obvious relationships between $\mathrm{N}$ application per paddock, soil concentration and $\mathrm{NO}_{3}{ }^{-}$ concentration. Figure 4 illustrates the different $\mathrm{N}$ distributions for 2004. Areas with medium to high $\mathrm{N}$ input e.g. on the south western corner had $\mathrm{NO}_{3}{ }^{-}$ concentrations below MAC during that year. Whereas in the middle of the farm lower $\mathrm{N}$ inputs were applied and $\mathrm{NO}_{3}{ }^{-}$concentrations were above MAC. 


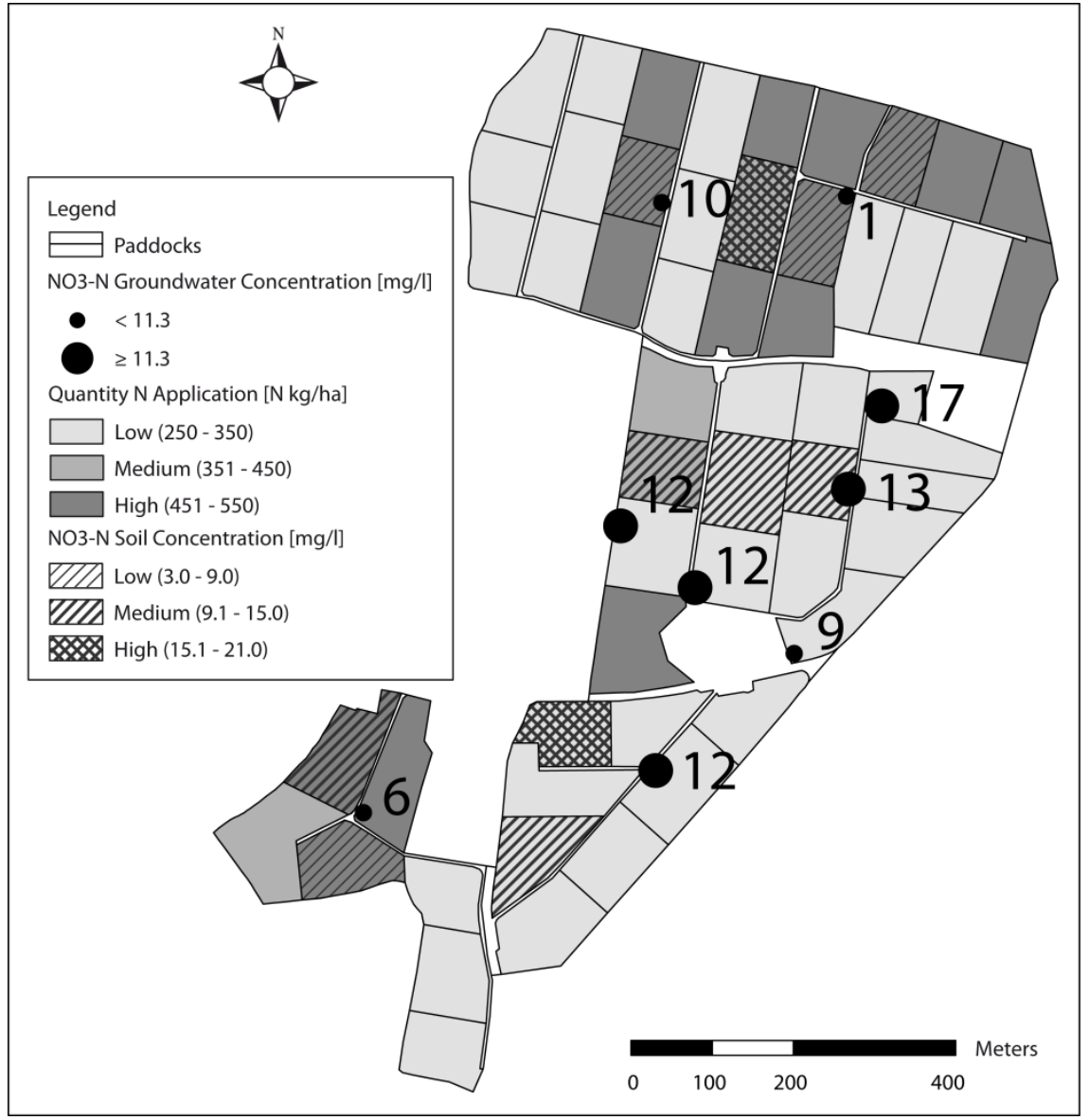

Figure 4: Example of GIS analysis for 2004 taken total $\mathrm{N}$ input on paddock level, $\mathrm{NO}_{3}-\mathrm{N}$ concentration in soil observed by [10] and mean monthly $\mathrm{NO}_{3}-\mathrm{N}$ concentrations in the boreholes into account.

\subsection{Statistical analysis}

The Cases created for $\mathrm{NO}_{3}^{-}$, TON, TN and DON using Normal-based regression with automatic selection had a range of $\mathrm{R}^{2}$ from 0.43 to 0.79 . Best results were achieved for $\mathrm{NO}_{3}{ }^{-}$from Case 1 . The $\mathrm{R}^{2}$ ranged from 0.68 to 0.75 including a slightly better result with year fitted as a factor than for selections for the whole period. For $\mathrm{NO}_{2}{ }^{-}$and $\mathrm{NH}_{4}{ }^{+}$the model selections for the logistic regressions were likely to be liberal as there were technical difficulties in fitting a repeated measures structure to the limited, year-averaged dataset.

Comparing Cases 1 to 4 for $\mathrm{NO}_{3}{ }^{-}$with each other, Case 1 seems to give the most interesting results from a climatic, geological and agronomic perspective. The $\mathrm{F}$ statistic indicates that the main factors influencing $\mathrm{NO}_{3}{ }^{-}$concentrations in 
groundwater were soil and rock thickness in the unsaturated zone to the top of the water table and the connections of the boreholes especially those already known by the tracer test of [12] $(\mathrm{BH} 7,8,9,10)$. Other factors showing an effect on $\mathrm{NO}_{3}{ }^{-}$concentrations in groundwater were borehole type (closed piezometer casing or open borehole), SMD, sunshine, year, fertilizer, grazing days, silage and slurry.

For TON, the $\mathrm{R}^{2}$ values are slightly lower than in the $\mathrm{NO}_{3}{ }^{-}$Cases ranging from 0.43 to 0.75 for year fitted and from 0.40 to 0.74 for the whole period. The best results were achieved for year fitted for Cases 1, 3 and 4. Case 2 seemed to have less predictive potential compared to the other scenarios. The variable selection outcomes for TON data were similar to the $\mathrm{NO}_{3}{ }^{-}$outcome as well. Climatic factors such as sunshine and SMD showed a significant influence together with geological settings such as thickness of soil and epikarst in the unsaturated zone to the water table. Farm management practices appeared to be associated with a 1 and 2 year time lag. These practices included fertilizer application and grazing days if year was included, silage if not and slurry for year fitted and the whole period.

The $\mathrm{R}^{2}$ values for $\mathrm{TN}$ and $\mathrm{DON}$ were around 0.5 , which indicated less explanatory power than the analysis of $\mathrm{NO}_{3}^{-}$and TON. Rainfall as a climatic factor had the most important influence. Nevertheless, farm management practices selected were fertilizer, slurry and grazing days. The outcome for DON in scenario 3 after a 2 year time shift proposed slurry to be the most important factor.

For $\mathrm{NO}_{2}^{-}$and $\mathrm{NH}_{4}^{+}$no single variable was most descriptive as the relative importance of the variables was similar, as indicated by the Wald statistic. In addition, the $\mathrm{R}^{2}$ values reached only 0.49 as the maximum value. In addition to the factors that were already observed in the aforementioned cases, reseeding, effective rainfall and DSW appeared to be the first time. DSW appeared only for $\mathrm{NH}_{4}{ }^{+}$and showed one of the highest influences on the $\mathrm{NH}_{4}{ }^{+}$concentrations.

Overall the statistical results showed that geological settings such as soil and rock thickness in the unsaturated zone to the top of the water table and climatic factors such as rainfall, sunshine and SMD consistently were important. The results indicated that the descriptive variables of farm management practices tended to become more important after 1 or 2 years of time lag, which concurs with those estimated by [9].

\section{Conclusion}

A statistical approach can be an effective method to explore the relationships between farm management, local weather variations and groundwater nutrient concentrations spatially and temporally in a highly complex free draining soil and karst aquifer environment. Therefore, it can be used to predict future changes in water quality. This is an ideal approach for farms within the remit of the EU WFD as it is nutrient concentration thresholds and not fluxes that are important. Over the 10 year monitoring period, the results of this study indicate that a combination of site characteristics (depth of the unsaturated zone, soil/subsoil 
and rock thickness), climatic factors (such as rainfall, sunshine and SMD) and agronomic practices (reduced fertilizer rate, appropriate slurry and DSW application strategy, minimum cultivation and strategic management of high risk zones) were important factors influencing nitrate loss to groundwater. Furthermore, these results indicate that improved nutrient management practices on a highly vulnerable site with free draining soil can have relatively quick impacts on groundwater quality and can lead to an achievement of the water quality targets set by for example the WFD, which aims to reach at least good water quality by 2015 , while assuming an estimated time lag of 1 to 2 years on such sites.

\section{References}

[1] Tilman, D., Cassman, K. G., Matson, P.A., Naylor, R., Polasky, S., Agricultural sustainability and intensive production practices. Nature, 418, pp. 671-677, 2002.

[2] Central Statistics Office Ireland (CSO), Crops and Livestock Survey June 2011 - Provisional Estimates. Central Statistics Office, Skehard Road, Cork, Ireland, p. 4, 2011.

[3] Godfray, H., Beddington, J.R., Crute, I.R., Haddad, L., Lawrence, D., Muir, J.F., Pretty, J., Robinson, S., Thomas, S.M., Toulmin, C., Food Security: The Challenge of Feeding 9 Billion People. Science, 327, pp. 812-818, 2010.

[4] Department of Agriculture, Fisheries and Food (DAFF), Food Harvest 2020 - A vision for Irish agri-food and fisheries, Agriculture House, Kildare St. Dublin 2, Ireland, 2010.

[5] Official Journal of the European Communities (OJEC), Directive 2000/60/EC of the European Parliament and of the council of 23rd October 2000 establishing a framework for Community action in the field of water policy. p. 72, 2000.

[6] European Community (EC), Council Directive 91/676/EEC of 21st May 1991 concerning the protection of waters against pollution by nitrates from agricultural sources. Off. J. Eur. Commun. L375, 1-8, 1991.

[7] Environmental Protection Agency (EPA), Water Quality in Ireland 2007 2009. p. 148, 2010.

[8] Dillon, P., Dellaby, L., Challenges from EU and International Environmental policy and legislation to animal production from temperate grassland. Irish J. Agr. Env. Res., 7, 51-68, 2009.

[9] Fenton, O., Schulte, R.P.O., Jordan, P., Lalor, S., Richards, K.G., Time lag: a methodology for the estimation of vertical and horizontal travel \& flushing timescales to nitrate threshold concentrations in Irish aquifers. Environ. Sci. Policy., 14, 419-431, 2011.

[10] Ryan, M., Brophy, C., Connolly, J., McNamara, K., Carton, O.T., Monitoring of nitrogen leaching on a dairy farm during four drainage seasons. Irish J. Agr. Food. Res., 45, 115-134, 2006. 
[11] Jahangir, M.M.R., Johnston, P., Khalil, M.I., Hennessy, D., Humphreys, J., Fenton, O., Richards, K.G., Groundwater: A pathway for terrestrial C and $\mathrm{N}$ losses and indirect greenhouse gas emissions. Agric. Ecosyst. Environ., 159, 40-48, 2012.

[12] Bartley, P., Nitrate responses in groundwater under grassland dairy agriculture. University of Dublin, p. 705, 2003.

[13] Schulte, R.P.O., Diamond, J., Finkele, K., Holden, N.M., Brereton, A.J., Predicting the soil moisture conditions of Irish grasslands. Iris J. Agric. Food Res., 44, 95-110, 2005.

[14] Fenton, O., Richards, K.G., Kirwan, L., Khalil, M.I., Healy, M.G., Factors affecting nitrate distribution in shallow groundwater under a beef farm in South Eastern Ireland. J. Environ. Manage. 90, 3135-3146, 2009

[15] Huebsch M, Horan B, Blum P, Richards KG, Grant J, Fenton O., Impact of agronomic practices of an intensive dairy farm on nitrogen concentrations in a karst aquifer in Ireland. Agric Ecosyst Environ, 179, 187-199, 2013. 